\title{
In vitro and in vivo development of mice morulae after storage in non-frozen conditions
}

\author{
Juan de Dios Hourcade ${ }^{1}$, Miriam Pérez-Crespo ${ }^{1}$, Alfredo Serrano ${ }^{2}$, Alfonso Gutiérrez-Adán ${ }^{1}$ and Belén Pintado ${ }^{2 *}$
}

\begin{abstract}
Background: Interchange of genetically modified (GM) mice between laboratories using embryos provides several advantages. Not only is transport stress avoided, but also the health status of the recipient colony is not compromised. Embryos do not need to be shipped in frozen stage, which requires expensive packaging in addition to a certain degree of expertise in order to freeze and thaw them correctly. The aim of this study was to examine different storage conditions and their effect on embryo viability in order to establish the feasibility of practical, non-frozen conditions for embryo shipment.

Methods: Mouse morulae developed in vivo (collected from donors $2.5 \mathrm{~d}$ post coitum) or in vitro (zygotes cultured until morulae stage) were stored, combining two different media (KSOMeq or KSOM-H) and temperatures (4 degrees $C, 15$ degrees $C$ and 37 degrees $C$ ) throughout 24 or 48 hours. After storage in vitro viability was assessed determining percentage of development to blastocyst and total cell number. In vivo viability was determined based on the number of implantations and living fetuses after embryo transfer of stored embryos. The storage effect at the molecular level was assessed by studying a gene pool involved in early development by quantitative RT-PCR.

Results: In vivo-produced morulae stored for 24 hours did not show differences in development up to the blastocyst stage, regardless of the storage type. Even though a decrease in the total cell number in vivo was observed, embryo development after embryo transfer was not affected. All 24 hour storage conditions tested provided a similar number of implantations and fetuses at day 14 of pregnancy. Morulae obtained from in vitro embryo culture collected at the 1-cell stage showed a decreased ability to develop to blastocyst after 24 hours of storage at 15 degrees $\mathrm{C}$ both in $\mathrm{KSOMeq}$ and $\mathrm{KSOM}-\mathrm{H}$. Concomitantly, a significant decrease of embryo implantation rates after transfer to recipients was also found. In order to further characterize the effect of non-frozen storage combining a molecular approach with the ordinary in vitro culture evaluation, embryos collected at the morula stage were submitted to the same storage conditions described throughout 48 hours. In vitro culture of those embryos showed a significant decrease in their developmental rate to blastocyst in both KSOMeq and KSOM-H at 15degrees C, which also affected the total number of cells. Gene transcription studies confirmed significant alterations in retrotransposons (Erv4 and lap) after $48 \mathrm{~h}$ of storage at 15 degrees C.
\end{abstract}

Conclusions: Our results show that both KSOMeq and KSOM-H can be equally used, and that several temperature conditions allow good survival rates in vitro and in vivo. Some of these storage conditions can substitute freezing in order to maintain embryo viability for 24-48 hours, providing a reliable and less demanding technical alternative for embryo interchanges.

Keywords: Embryo, Mouse, Storage

\footnotetext{
* Correspondence: bpintado@cnb.csic.es

${ }^{2}$ Centro Nacional de Biotecnología, CSIC. C/ Darwin 3, Madrid 28049, Spain

Full list of author information is available at the end of the article
} 


\section{Background}

An increasing number of genetically modified (GM) mice are exchanged between laboratories every year. National and international legislations enforce reducing the number of laboratory animals used for research purposes, and one clear way to accomplish this goal is to avoid the duplication of a GM line that has been already generated. Unfortunately, many of these lines are not stored in international repositories where cryobanking is well-established, but they are kept alive in animal facilities. Transport of live animals poses certain risks: not only may it compromise the health status of the receiving facility, but there is also an animal welfare issue and increasingly restrictive conditions from air and ground carriers.

On the other hand, cryopreserved embryos allow safe transport, but this approach demands a certain degree of expertise to freeze and thaw them correctly [1]. Moreover, the containers used are costly and should be returned with the concomitant expense. Some approaches have explored the feasibility of alternative methods using, for instance, intermediate recipients $[2-4]$, or specific temperatures [5,6]. In these studies, 2-cell embryos were used, even though embryos of certain mice strains are prone to 2-cell blockage when cultured in suboptimal conditions [7]. A simple way to overcome this risk is to use embryos in later stages of development, like morulae, that still allow 48 hours of autonomy. This time span is enough to reach most destinations and can easily complement cryopreservation without a need for specific equipment and expertise in cryobiology. Transport of embryos in liquid stage can be achieved either in culture media or in standard embryo holding media like M-2, where bicarbonate is substituted with HEPES. With this replacement $\mathrm{pH}$ is stabilized when embryos are handled; however, bicarbonate is necessary for the optimal development of embryos and long-term exposure to holding media might be detrimental.

Our aim was to first explore different storage conditions, trying to simplify the technical skills needed in order to promote the use of embryos for exchanging GM lines, even with facilities unfamiliar with thawing procedures. Secondly, we tried to characterize how gene expression patterns of some relevant genes during preimplantational development are affected by storage conditions.

\section{Methods}

\section{Reagents and Media}

All chemicals and media were purchased from Sigma Chemical Co. (Madrid, Spain), unless otherwise stated.

\section{Embryo production}

Female B6CBAF1 mice aged 6-8 weeks old were induced to superovulate with an intraperitoneal injection of 7.5 IU equine chorionic gonadotropin (eCG, Folligon, Intervet, The Netherlands), followed $48 \mathrm{~h}$ later, by $5 \mathrm{IU}$ of human chorionic gonadotropin (hCG). Immediately after hCG administration, females were paired with adult intact mice of the same genetic background in a individual cage overnight. All animal experiments were approved by our Institutional Review Board according to the European and Spanish legislation.

\section{Embryo collection}

One-cell embryos were collected from the ampulla of females which were euthanized by cervical dislocation, $20 \mathrm{~h}$ post-hCG administration. Cumulus cells were removed by exposure to hyaluronidase as described [8] and zygotes were washed in M2 medium and cultured in Potassium $\left(\mathrm{K}^{+}\right)$Simplex Optimized Medium (KSOM) microdrops [9] covered with mineral oil at $37^{\circ} \mathrm{C}$ and $5 \%$ $\mathrm{CO}_{2}$ until the morula stage. Morulae embryos developed in vivo were collected $66-78 \mathrm{~h}$ post-hCG administration by flushing both the oviduct and the upper part of the uterine horn with M2 medium.

\section{Storage conditions}

Three temperatures $\left(4^{\circ} \mathrm{C}, 15^{\circ} \mathrm{C}\right.$ and $\left.37^{\circ} \mathrm{C}\right)$ and two media (KSOM and KSOM-H) were chosen. Additionally, two storage lengths (24 and 48 hours) were studied in order to assess the effect of storage on in vitro development. Buffered media (KSOM-H) for embryo storage was prepared by adding HEPES $(20 \mathrm{mM})$ to KSOM, maintaining bicarbonate at the original concentration of $25 \mathrm{mM}$. $\mathrm{KSOM}$ composition is shown at 23. Both media were prepared every 2 weeks and filtered through $0.22 \mu \mathrm{m}$ pore and stored at $4^{\circ} \mathrm{C}$ until use.

For experiments 1 and 2 of the in vitro study (Figure 1), twenty three B6CBAF1 females and eight B6CBAF1 males were used: morulae collected at day 2.5 dpc. were placed in cryotubes filled with pre-equilibrated $\mathrm{KSOM}(5 \mathrm{ml})$ for $24 \mathrm{~h}$ at $5 \% \mathrm{CO}_{2}$ (KSOMeq) or KSOMHEPES ( $5 \mathrm{ml}, 20 \mathrm{mM}$ HEPES, KSOM-H) at $\mathrm{pH}$ 7.3-7.4 and sealed with parafilm. Each tube contained 20-30 embryos; this high volume of medium allows a slow decrease in $\mathrm{CO}_{2}$ concentration and gradual changes in temperature. Randomly selected tubes were placed by couples (KSOMeq and $\mathrm{KSOM}-\mathrm{H})$, in a refrigerator $\left(4^{\circ} \mathrm{C}\right)$, a refrigerated chamber $\left(15^{\circ} \mathrm{C}\right)$ and in an incubator without $\mathrm{CO}_{2}\left(37^{\circ} \mathrm{C}\right)$. Twenty four hours (experiment 1$)$ or 48 hours later (experiment 2), embryos were recovered from each tube and set in culture (KSOM microdrops). In each experiment, non-stored embryos were placed in culture in parallel to serve as a control group. 


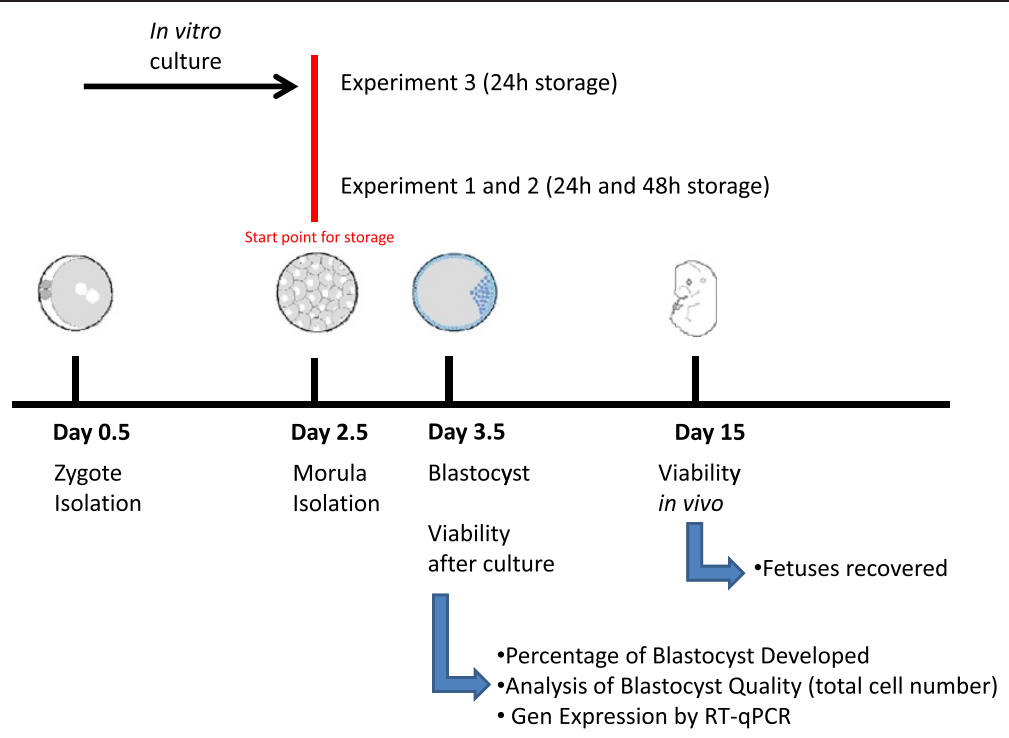

Figure 1 Scheme of experimental design of the study. Embryos cultured from zygote to morula stage were subjected to 24 hours of simulated shipment (Experiment 3). Embryos developed in vivo were subjected to either 24 hours (Experiment 1) or 48 hours (Experiment 2) of simulated shipment. In all cases, embryo development to blastocyst stage and total cell number was reordered. For 24 hour experiments, embryo transfer to surrogate mother foster was performed. Additionally, in the 48 hour experiment, gene expression analysis was carried out.

In experiment 3 (in vitro study), thirteen B6CBAF1 females and six B6CBAF1 males were used: 1-cell embryos collected on day 0.5 were placed in culture for 48-50 hours until reaching the morula stage. As described for the two previous experiments, groups of 20-30 embryos were placed in cryotubes filled with preequilibrated (24 h before) KSOM ( $5 \mathrm{ml}$ ) or KSOM-H and randomly assigned to one of the three storage conditions selected: $4^{\circ} \mathrm{C}, 15^{\circ} \mathrm{C}$ or $37^{\circ} \mathrm{C} .24$ hours later, embryos were recovered from each tube and placed in culture. For this experiment, a group of non-stored embryos obtained in the same way was set in culture as a control group for development.

\section{$\mathrm{pH}$ determination of holding media under the different storage conditions tested}

In order to evaluate the $\mathrm{pH}$ fluctuations that might occur in equilibrated and buffered media used for embryo storage, $\mathrm{pH}$ measurements were performed on samples in triplicate, maintained under experimental storage conditions at $0,90,180$ and 300 minutes, $24 \mathrm{~h}$, $48 \mathrm{~h}$ and $72 \mathrm{~h}$. for each treatment. Mean values were used as $\mathrm{pH}$ measurement at each time point.

\section{In vitro evaluation of viability of stored embryos}

In vitro viability was evaluated in three different groups: in vivo collected morulae stored for 24 hours (experiment 1) or 48 hours (experiment 2) and morulae obtained from 1-cell embryos after in vitro culture and then stored for 24 hours (experiment 3). To perform these experiments, seventy-five B6CBAF1 females were used as embryo donors, seventy-three CD-1 females as surrogate mothers; ten B6CBAF1 males and ten CD1 males were used to establish matings. In all cases, embryos were randomly distributed into the six combinations of media and temperature described, plus into a control group of cultured embryos without previous storage. Two parameters were determined: percentage of development to blastocyst, and total cell count. To determine the in vitro viability based on development to blastocyst, embryos were recovered after storage from cryotubes and placed in pre-equilibrated KSOM microdrops. After incubation at $37^{\circ} \mathrm{C}$ and $5 \% \mathrm{CO} 2$ for $24-36 \mathrm{~h}$, the number of expanded blastocysts was recorded.

The total cell number of blastocyst which had developed under the different storage conditions and in control groups was determined by nuclei staining. Embryos were placed in M2 medium drops supplemented with Hoechst $33342(1 \mu \mathrm{g} / \mathrm{ml})$ and allowed to stain during 30 minutes at $37^{\circ} \mathrm{C}$. Blastocysts were placed on a glass slide, sealed with a cover slide and observed under a Nikon Optiphot-2 fluorescence microscope with an appropriate filter set (Blue: 450-490 nm excitation filter, $515 \mathrm{~nm}$ barrier filter).

\section{In vivo evaluation of viability of stored embryos}

Embryos stored under the different conditions were, immediately after the storage period, surgically transferred to surrogate mothers in order to establish their in vivo viability. 15 to 20 embryos recovered from the different treatments were transferred into the left oviduct of 0.5 pseudopregnant CD-1 females (Harlan), plugged by 
vasectomised males. At day 14 of gestation, recipients were euthanized and uterine horns were isolated to record the number of living fetuses, resorptions and the total number of implantations.

\section{Quantitative RT-PCR}

Gene expression studies were performed on in vivo collected morulae stored for 48 hours in order to maximize effects of storage without interference of previous in vitro culture. The quantification of all gene transcripts was carried out by real time quantitative RT-PCR in three replicates (10 embryos per replicate) [10]. A total of 210 blastocysts were used; sixteen B6CBAF1 females and six B6CBAF1 males were used to collect the embryos. PCR was performed using a Rotorgene 2000 Real Time Cycler $^{\text {TM }}$ (Corbett Research, Sydney, Australia) and SYBR Green (Molecular Probes, Eugene, OR) as a double-stranded DNA-specific fluorescent dye. The PCR reaction mixture $(25 \mu \mathrm{l})$ contained $2.5 \mu \mathrm{l} 10 \times$ buffer, $3 \mathrm{mM} \mathrm{MgCl}$, $2 \mathrm{U}$ Taq Express (MWGAG Biotech, Ebersberg, Germany), $100 \mu \mathrm{M}$ of each dNTP, and $0.2 \mu \mathrm{M}$ of each primer (Table 1). In addition, the double-stranded DNA dye, SYBR Green I, (1:3000 of $10000 \times$ stock solution) was included in each reaction. The PCR protocol included an initial step of $94^{\circ} \mathrm{C}$ ( $2 \mathrm{~min})$, followed by 40 cycles of $94^{\circ} \mathrm{C}(15 \mathrm{~s}), 56-59^{\circ} \mathrm{C}$ (30 s) and $72^{\circ} \mathrm{C}(30 \mathrm{~s})$. Fluorescent data was acquired at $80-85^{\circ} \mathrm{C}$. The melting protocol consisted of holding at $40^{\circ} \mathrm{C}$ for $60 \mathrm{~s}$, and then heating from 50 to $94 \mathrm{C}$, holding at each temperature for $5 \mathrm{~s}$ while monitoring fluorescence. Product identity was confirmed by ethidiumbromide-stained $2 \%$ agarose gel electrophoresis. As negative controls, tubes were prepared in which RNA or reverse transcriptase was omitted during the RTreaction. The comparative $\mathrm{CT}$ method was used for quantitation of expression levels. The quantification was normalized to the endogenous control histone H2a.z. The normality of amplification was checked for each

Table 1 Total cell counts of blastocysts developed after morulae (in vivo developed) storage during 24 hours

\begin{tabular}{llll}
\hline \multicolumn{1}{c}{ Treatment } & & $\begin{array}{l}\text { Number of } \\
\text { blastocysts } \\
\text { analysed }\end{array}$ & $\begin{array}{l}\text { Total cell } \\
\left(\mathbf{N}^{\circ} \text { of cells) }\right.\end{array}$ \\
\hline Media & Temperature & & \\
\hline Control & $37^{\circ} \mathrm{C}$ & 26 & $59.26 \pm 2.86^{\mathrm{a}}$ \\
KSOM & $4^{\circ} \mathrm{C}$ & 17 & $40.77 \pm 1.96^{\mathrm{b}}$ \\
KSOM-HEPES & & 21 & $48.94 \pm 2.67^{\mathrm{b}}$ \\
KSOM & $15^{\circ} \mathrm{C}$ & 19 & $40.24 \pm 2.05^{\mathrm{b}}$ \\
KSOM-HEPES & & 21 & $44.58 \pm 2.12^{\mathrm{b}}$ \\
KSOM & $37^{\circ} \mathrm{C}$ & 22 & $46.10 \pm 3.11^{\mathrm{b}}$ \\
KSOM-HEPES & & $50.46 \pm 3.93^{\mathrm{b}}$ \\
\hline
\end{tabular}

Mean \pm SEM. Different letters indicate significant differences between treatments. ANOVA followed by Student-Newman-Kleus post hoc test was performed. sample. The internal control is used to normalize the PCRs for the amount of RNA added to the reverse transcription reactions and to minimize variability in the results due to differences in the $\mathrm{RT}$ efficiency and/or RNA integrity among the different embryo groups. The CT value obtained for each amplified gene was normalized to the CT value of an internal control, histone $\mathrm{H} 2 \mathrm{a}$. z. Within this region of the amplification curve, each difference of one cycle is equivalent to a doubling of the amplified product of the PCR. According to the comparative CT method, the $\triangle \mathrm{CT}$ value was determined by subtracting the $\mathrm{H} 2 \mathrm{a} \mathrm{CT}$ value for each sample from each gene CT value of the sample. Calculation of $\Delta \Delta \mathrm{CT}$ involved using the highest sample $\Delta \mathrm{CT}$ values (i.e. the sample with the lower target expression) as an arbitrary constant to subtract from all other $\triangle \mathrm{CT}$ sample values. Fold changes in the relative gene expression of the target was determined by using the formula, 2- $\Delta \Delta \mathrm{CT}$ [11].

\section{Experimental design}

Our aim was to assess viability of embryos stored in different conditions that could be easily used for transport without requirement of specific containers or specialized recovery techniques. Temperatures were selected to include those whereat embryos could be in a latent stage $\left(4^{\circ} \mathrm{C}\right)[12]$, or at a physiological developmental temperature $\left(37^{\circ} \mathrm{C}\right)[13,14]$. An additional temperature was selected whereat metabolism could be retarded and easily maintained without complex equipments $\left(15^{\circ}\right)$. These temperatures were combined with 2 different media: KSOMeq and KSOM-H. Three different studies were designed to achieve this goal. In the first study (Figure 1) we assessed in vitro viability after storage in three experiments: In experiment 1 , freshly collected morulae were stored in different conditions for 24 hours. In experiment 2, the same storage conditions were tested for 48 hours, and in experiment 3, embryos were collected at the 1-cell stage, cultured in vitro until the morula stage and then submitted to the same storage conditions for 24 hours as in experiment 1 . In vitro viability was determined based on percentage of development in culture and assessing total cell number.

In the second study, in vivo viability of stored embryos was evaluated based on the number of live implantations and resorptions after being transferred into foster mothers. In vivo assessment of viability was circumscribed to embryos stored for $24 \mathrm{~h}$; either freshly collected morulae or morulae obtained after in vitro culture of embryos collected at the 1-cell stage, since in those groups, conditions were represented that, in vitro, were either detrimental or did not affect embryo development.

The third study explored the effect of storage conditions on expression of some genes closely related to 
early embryo development. To determine these levels of gene expression, we chose embryos obtained in vivo stored for $48 \mathrm{~h}$ under the different conditions studied. We selected this time condition in order to examine gene expression after storage in those combinations of temperature and media in which a relevant effect was assessed. Correlation between gene expression and physiological aspects (embryo development in culture) allows for defining new molecular aspects of embryo physiology.

\section{Statistical analysis}

Statistical analyses were performed using SigmaStat version 3.1.1 software (Jandel Scientific, San Rafael, CA). Data is given as the mean \pm S.E.M. Comparison of the differences between means for each treatment were done using ANOVA followed by Student-Newman-Kleus post hoc test.

\section{Results}

In vitro development after storage for $\mathbf{2 4}$ or $\mathbf{4 8}$ hours

None of the 24 hours storage conditions evaluated (Figure 1.) affected in vitro development of embryos collected at the morula stage. Almost $100 \%$ of morulae assigned to the control group (submitted to culture without previous storage) developed to blastyocyst (Figure 2.) Among those morulae stored for 24 hours in the 6 conditions tested, one particular storage condition (KSOM-H at $15^{\circ} \mathrm{C}$ ) decreased percentage of blastocyst formation to $72 \%$, but this decrease was not statistically significant.

When storage time is extended to 48 hours, embryos stored at $4^{\circ} \mathrm{C}$ (both KSOMeq and KSOM-H treatments) showed the highest level of development, but these values were statistically similar to those found in embryos stored at $37^{\circ} \mathrm{C}$, regardless of the medium used. Embryo development decreased to $60 \%$ in both $15^{\circ} \mathrm{C}$ treatments (Figure 3).

In order to examine the effect of in vitro culture on morulae embryos' ability to be stored under several conditions, a pool of zygotes was retrieved on Day 1 and placed in culture for 60 hours until reaching the morula stage (Figure 1). Then, embryos were allocated to the six storage conditions described for the rest of experiments, and a group remained in culture to serve as control. Embryo viability was significantly compromised under two of the conditions tested (KSOMeq and KSOM-H at $15^{\circ} \mathrm{C}$ ). While the control group showed developing rates close to $90 \%$, a significant decrease in viability was observed for embryos stored at $15^{\circ} \mathrm{C}$, regardless of the medium selected. Blastocyst development dropped to $30 \%$ in KSOMeq and to $40 \%$ in KSOM-H. In the remaining groups, no differences were evidenced when compared to the control. Embryos stored at $4^{\circ} \mathrm{C}$ (both KSOMeq and KSOM-H) showed developing rates close to $70 \%$, while embryos stored at $37^{\circ} \mathrm{C}$ showed viability rates close to $80 \%$ and $70 \%$ (KSOMeq and KSOM-H, respectively) (Figure 4 ).

\section{Total cell number}

Correlation between the cell number in the blastocyst, and implantation ability was reported several years ago [15]. However, this parameter correlates poorly with morphology, a visual character widely used as a noninvasive marker for embryo quality. For this reason, morphological criterion should be reinforced by other parameters [16]. In addition to morphology, we analyzed the total cell number of morulae developed in vivo

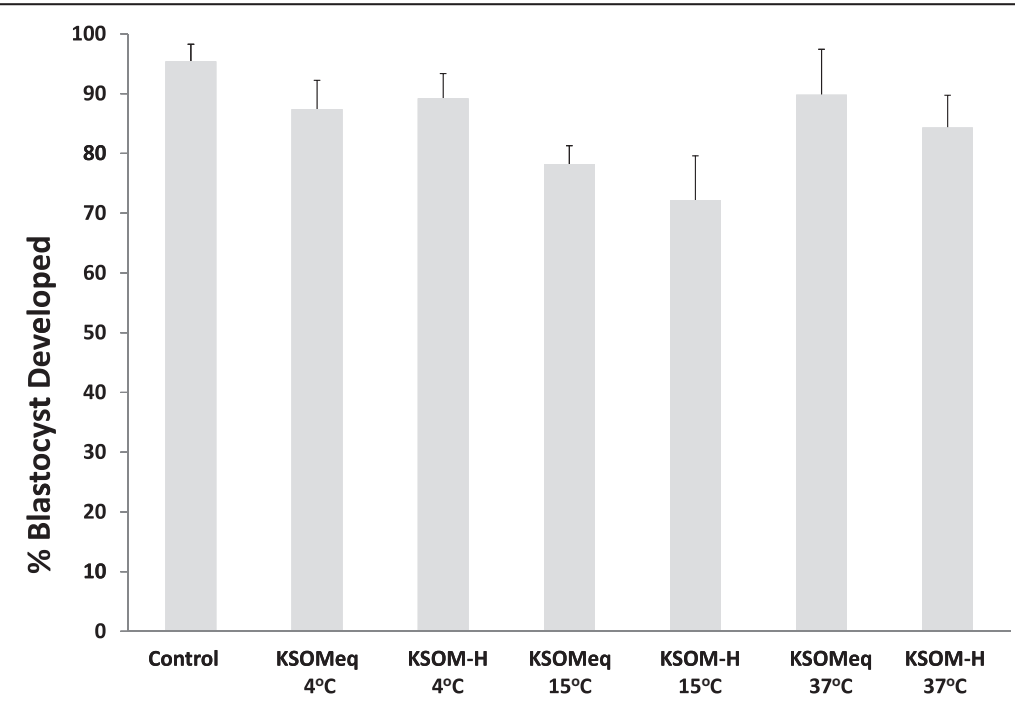

Figure 2 Development of embryos collected at the morula stage stored for 24 hours in KSOM and KSOM-HEPES at $4^{\circ} \mathrm{C}, 15^{\circ} \mathrm{C}$ and $37^{\circ} \mathrm{C}$. Mean \pm SEM. Significant differences were denoted by different letters. ANOVA analysis was performed. 


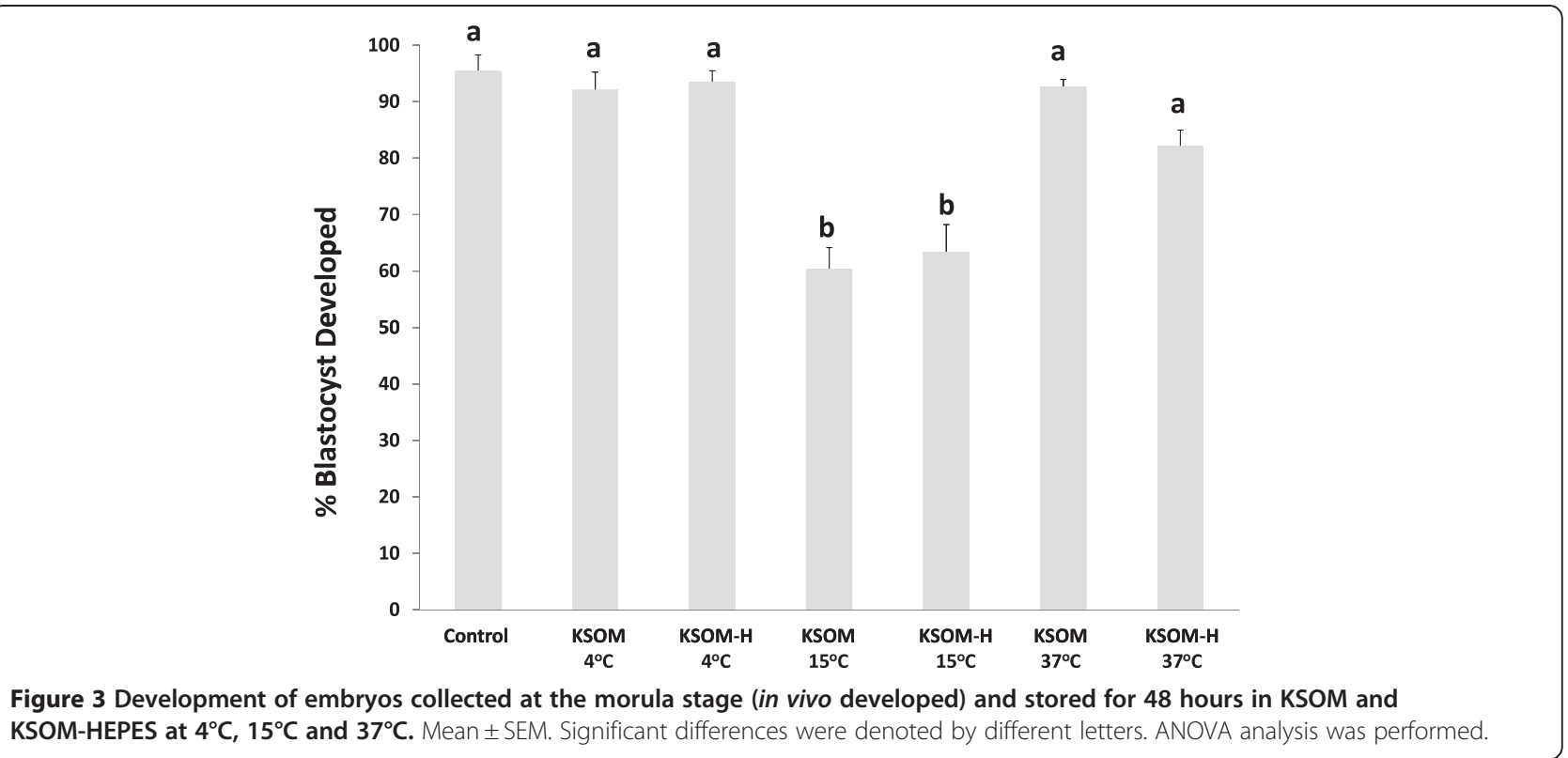

subjected to storage during 24 hours. As a result of this study, we observed a significant cell number decrease in all treatments in comparison with the control group (Table 1), but no differences were found when we compared this parameter within the different experimental conditions tested.

In vivo developed morulae that were stored for 48 hours showed a significant decrease in cell count compared to the control group in both media (KSOMeq and $\mathrm{KSOM}-\mathrm{H})$ in embryos stored at $15^{\circ}$ and $37^{\circ} \mathrm{C}$ (Table 2.). Conversely, $4^{\circ} \mathrm{C}$ treatments did not differ.
When cell numbers were compared within the two groups at $37^{\circ} \mathrm{C}$, KSOMeq provided higher values than $\mathrm{KSOM}-\mathrm{H}$, suggesting a detrimental effect of HEPES at such a temperature (Table 3 ).

In vitro developed morulae showed a significant decrease in cell number in all treatments, except in KSOM at $37^{\circ} \mathrm{C}$, with the highest decrease found in KSOM-H at $15^{\circ} \mathrm{C}$ and at $37^{\circ} \mathrm{C}$. This fact indicates that media alkalinization proved to be less harmful than HEPES presence, since we found a significant difference in this temperature (52.39 vs 32.83 ( $\mathrm{KSOM}$ at $37^{\circ} \mathrm{C}$ vs $\mathrm{KSOM}$ -

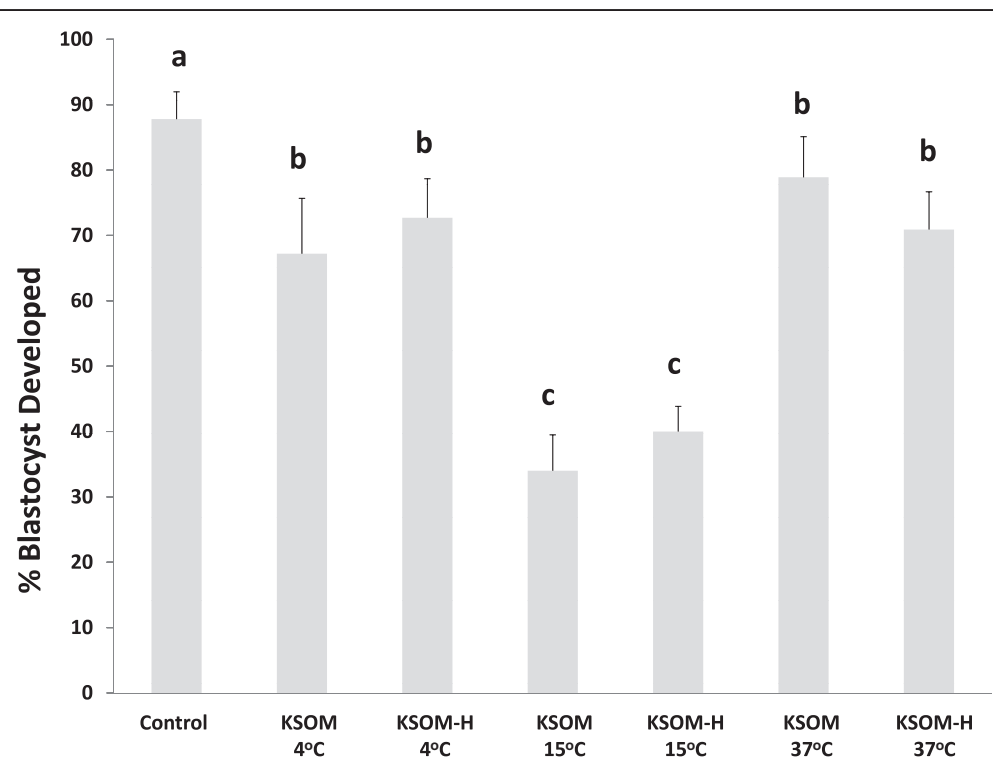

Figure 4 Development of embryos collected at 1-cell stage, cultured to morulae (in vitro developed) and stored for 24 hours in KSOM and KSOM-HEPES at $4^{\circ} \mathrm{C}, 15^{\circ} \mathrm{C}$ and $37^{\circ} \mathrm{C}$. Mean \pm SEM. Significant differences were denoted by different letters. ANOVA analysis was performed. 
Table 2 Total cell count of blastocysts developed after morulae (in vivo developed) storage during 48 hours

\begin{tabular}{|c|c|c|c|}
\hline \multicolumn{2}{|c|}{ Treatment } & \multirow{2}{*}{$\begin{array}{l}\text { Number of } \\
\text { blastocysts } \\
\text { analysed }\end{array}$} & \multirow{2}{*}{$\begin{array}{l}\text { Total cell } \\
\left(\mathbf{N}^{\circ} \text { of cells) }\right.\end{array}$} \\
\hline Media & Temperature & & \\
\hline Control & $37^{\circ} \mathrm{C}$ & 23 & $69.43 \pm 3.19^{a}$ \\
\hline KSOM & $4^{\circ} \mathrm{C}$ & 15 & $64.67 \pm 1.97^{\mathrm{a}}$ \\
\hline KSOM-HEPES & & 21 & $70.05 \pm 2.80^{a}$ \\
\hline KSOM & $15^{\circ} \mathrm{C}$ & 14 & $41.14 \pm 2.66^{b}$ \\
\hline KSOM-HEPES & & 23 & $43.30 \pm 2.12^{b}$ \\
\hline KSOM & $37^{\circ} \mathrm{C}$ & 39 & $52.97 \pm 1.39^{c}$ \\
\hline KSOM-HEPES & & 22 & $38.15 \pm 1.47^{b}$ \\
\hline
\end{tabular}

Mean \pm SEM. Different letters indicate significant differences between treatments. ANOVA followed by Student-Newman-Kleus post hoc test was performed.

$\mathrm{H}$ at $\left.37^{\circ} \mathrm{C}\right)$ ). This effect was not present in those embryos collected as morulae and subjected to the same storage conditions as those described in experiment 1 (Table 3). This suggests that the coincidence of HEPES presence was necessary with other detrimental conditions in order to produce a measurable negative effect.

\section{In vivo viability of stored embryos: analysis of implantations and fetuses}

This study was carried out with embryos stored for $24 \mathrm{~h}$, either freshly collected morulae or morulae obtained after an in vitro culture of embryos collected at the 1cell stage. In vivo viability was measured by determining the number of live implantations and resorptions after embryo transfer into foster mothers. Table 4 summarizes the in vivo viability of embryos collected at the morula stage and stored for 24 hours in the six conditions assayed, compared to a control group of transfers performed with embryos collected at the morula stage and transferred without further storage. It may be observed that none of the storage conditions produced a significant decrease in implantation percentages compared to

Table 3 Total cell counts of blastocysts developed after morulae (in vitro developed) storage during 24 hours

\begin{tabular}{|c|c|c|c|}
\hline \multicolumn{2}{|c|}{ Treatment } & \multirow{2}{*}{$\begin{array}{l}\text { Number of } \\
\text { blastocysts } \\
\text { analysed }\end{array}$} & \multirow{2}{*}{$\begin{array}{l}\text { Total cell } \\
\text { ( } \mathbf{N}^{\circ} \text { of cells) }\end{array}$} \\
\hline Media & Temperature & & \\
\hline Control & $37^{\circ} \mathrm{C}$ & 19 & $54.73 \pm 1.74^{a}$ \\
\hline KSOM & $4^{\circ} \mathrm{C}$ & 24 & $40.00 \pm 1.98^{b}$ \\
\hline KSOM-HEPES & & 16 & $44.88 \pm 2.38^{b}$ \\
\hline KSOM & $15^{\circ} \mathrm{C}$ & 18 & $43.63 \pm 1.85^{b}$ \\
\hline KSOM-HEPES & & 13 & $32.61 \pm 3.08^{c}$ \\
\hline KSOM & $37^{\circ} \mathrm{C}$ & 18 & $52.39 \pm 2.97^{a}$ \\
\hline KSOM-HEPES & & 15 & $32.83 \pm 2.96^{c}$ \\
\hline
\end{tabular}

Mean \pm SEM. Different letters indicate significant differences between treatments. ANOVA followed by Student-Newman-Kleus post hoc test was performed. the control. Values oscillated between $41 \%$ (KSOMeq at $15^{\circ} \mathrm{C}$ ) to $66 \%\left(\mathrm{KSOM}-\mathrm{H}\right.$ at $\left.15^{\circ} \mathrm{C}\right)$, without significant differences. However a significant raise of resorptions was observed in the $\mathrm{KSOMeq}$ at $15^{\circ} \mathrm{C}(38 \%)$ compared to the $16 \%$ registered in the control group.

Survival of control embryos collected at the 1-cell stage, cultured to the morula stage and then transferred into pseudopregnant recipients without storage, was $24 \%$ as opposed to the $41 \%$ of live fetuses obtained after transfer of embryos collected as morulae and immediately transferred. This difference highlights the detrimental effect of in vitro culture on viability. All treatments provided a similar number of fetuses recovered on day 14 compared to the control group, with the exception of $\mathrm{KSOM}-\mathrm{H}$ at $15^{\circ} \mathrm{C}$. In this case, the percentage of live fetuses decreased to $5 \%$. This same group showed a significantly higher resorption. However, there were no differences between treatments regarding the total number of implantations (Table 5). These values suggest that the embryo's ability to implant is preserved, but that ICM cells are not able to develop into fetuses, indicating a possible misregulation of genes related to post-implantation development.

\section{Transcription analysis by real time PCR}

Since our findings suggested a certain misregulation of the genes crucial for embryo development after implantation, we evaluated the effect of storage on mRNA expression. For that purpose, we chose in vivo collected morulae stored for $48 \mathrm{~h}$. Gene screening aimed to check different developmental functions (Table 6). Bax versus $\mathrm{Bcl}-2$ ratio was used as prognostic marker of apoptosis. None of the assayed conditions altered the expression level of $B a x$, a proapoptotic gene. On the contrary, $\mathrm{Bcl}-2$, an antiapoptotic gene, was downregulated in all experimental conditions compared to the control and, as a consequence, $\mathrm{Bax} / \mathrm{Bcl}-2$ ratio was altered in all treatments assayed when compared to the control group. This indicates the occurrence of apoptotic events during storage (Figure 6A).

Retrotransposon expression, frequently impaired in stressful embryo situations, was analysed measuring mRNA levels of Erv4 and Iap genes. Erv4 was significantly upregulated in $\mathrm{KSOMeq}$ and $\mathrm{KSOM}-\mathrm{H}$ at $15^{\circ} \mathrm{C}$, Furthermore, Iap showed a marked increase in mRNA levels in embryos kept in $\mathrm{KSOM}-\mathrm{H}$ at $5^{\circ} \mathrm{C}$ when compared to controls. These changes in retrotransposon transcription indicate some alterations in the epigenetic control of their expression. While no effect was detected in the expression of reverse transcriptase for telomerase (Tert), Gaj1 (Connexin 43) showed a decrease in levels of transcripts at $15^{\circ}$ and $37^{\circ}$, both in KSOMeq and in KSOM-H. This situation could have detrimental effects on the implantation of stored embryos, advising against 
Table 4 Number of fetuses, resoprtions and total number of implantations after embryo transfer of morulae (in vivo developed) stored during 24 hours

\begin{tabular}{|c|c|c|c|c|c|c|}
\hline \multicolumn{2}{|c|}{ Treatments } & \multirow{2}{*}{$\begin{array}{l}\text { Number of } \\
\text { experiments }\end{array}$} & \multirow{2}{*}{$\begin{array}{l}\text { Embryos } \\
\text { transferred }\end{array}$} & \multirow[t]{2}{*}{ Fetuses (\%) } & \multirow[t]{2}{*}{ Resorptions (\%) } & \multirow{2}{*}{$\begin{array}{l}\text { Total } \\
\text { implantations (\%) }\end{array}$} \\
\hline Media & Temperature & & & & & \\
\hline Control & $37^{\circ} \mathrm{C}$ & 5 & 70 & $41(58.48 \pm 7.76)^{a}$ & $11(15.90 \pm 4.98)^{\text {nd }}$ & $52(74.37 \pm 6.83)^{\text {nd }}$ \\
\hline KSOM & $4^{\circ} \mathrm{C}$ & 5 & 77 & $38(49.59 \pm 9.57)^{a}$ & $16(21.15 \pm 8.23)$ & $54(70.75 \pm 13.63)$ \\
\hline KSOM-HEPES & & 5 & 73 & $30(42.92 \pm 5.55)^{\mathrm{a}}$ & $15(32.34 \pm 7.41)$ & $45(75.26 \pm 6.18)$ \\
\hline KSOM & $15^{\circ} \mathrm{C}$ & 5 & 80 & $33(41.05 \pm 4.02)^{\mathrm{a}}$ & $31(38.70 \pm 4.63)$ & $64(79.75 \pm 5.31)$ \\
\hline KSOM-HEPES & & 5 & 71 & $47(66.29 \pm 2.79)^{\mathrm{a}}$ & $14(20.19 \pm 3.57)$ & $61(86.47 \pm 4.72)$ \\
\hline KSOM & $37^{\circ} \mathrm{C}$ & 5 & 78 & $41(52.95 \pm 9.97)^{\mathrm{a}}$ & $18(22.16 \pm 6.41)$ & $59(75.11 \pm 10.62)$ \\
\hline KSOM-HEPES & & 5 & 78 & $44(56.21 \pm 6.28)^{a}$ & $19(24.01 \pm 10.22)$ & $63(80.23 \pm 5.81)$ \\
\hline
\end{tabular}

Mean \pm SEM. Different letters indicate significant differences between treatments. ANOVA followed by Student-Newman-Kleus post hoc test was performed.

the use of these temperature conditions for embryo transport (Figure 6D).

Nanog transcript levels decreased in all treatments compared with the control group, but the effect was especially remarkable in $\mathrm{KSOM}$ and $\mathrm{KSOM}-\mathrm{H}$ at $15^{\circ}$ and $37^{\circ} \mathrm{C}$. A similar pattern had Pou5F1 (Oct 3/4), decreasing transcripts in $\mathrm{KSOM}$ at $15^{\circ} \mathrm{C}$ and both $\mathrm{KSOM}$ as KSOM-H at $37^{\circ} \mathrm{C}$ (Figure $6 \mathrm{C}$ ).

Gapdh is a gene involved in metabolic functions, such as in transcription and programmed cell death. In this case, it had a slightly significative tendency to be downregulated at higher temperatures. $\mathrm{KSOM}$ at $15 \mathrm{C}$ and $\mathrm{KSOM}-\mathrm{H}$ at $37^{\circ} \mathrm{C}$ were the groups in which downregulation was more evident (Figure 6B).

\section{Holding medium $\mathrm{pH}$ fluctuation during storage}

Figure 5 summarizes $\mathrm{pH}$ media fluctuation. All experimental conditions provided initial $\mathrm{pH}$ under 7.6. However after keeping equilibrated $\mathrm{KSOM}$ at $37^{\circ} \mathrm{C}$ for 48 hours, media underwent a consistent basification reaching values close to 8 , demonstrating that the buffering activity of bicarbonate could not guarantee $\mathrm{pH}$ conditions, even in a tight sealed vial.

Since our intention was to test standard recipients within the reach of any laboratory, we performed the study in cryotubes. These recipients close tightly and provide a theoretical way to isolate the growth media in which embryos could be stored. Analysis of $\mathrm{pH}$ revealed a significant difference in $\mathrm{pH}$ values of KSOMeq at $37^{\circ} \mathrm{C}$ in comparison with the the rest of treatments. These findings demonstrated that cryotubes allow $\mathrm{CO}_{2}$ difussion into the air and a concomitant basification that was not buffered by the presence of HEPES as in KSOM-H, and that this diffusion was potentiated by temperature [17]. More efficient ways to preserve storage environment have been reported [18], that should be considered as an alternative if transport has to take place under such conditions.

\section{Discussion}

Shipment of embryos is a good alternative to the exchange of live animals for several reasons. The intrinsic sterility of embryos surrounded by an intact zona pellucida obviates differences in the microbiologic levels of donor and recipient laboratories [19], [20]. Transport of embryos also has the advantage of avoiding stressful conditions that may affect animals for several days. In addition, use of embryos when dealing with genetically modified animals avoids any possibility of accidental escape, an important issue in risk assessments. Embryos of different mammalian species have been successfully transported in frozen stage [21-23]. Cryopreserved

Table 5 Number of fetuses, resoprtions and total number of implantations after embryo transfer of morulae (in vitro developed) stored during 24 hours

\begin{tabular}{|c|c|c|c|c|c|c|}
\hline \multicolumn{2}{|c|}{ Treatments } & \multirow{2}{*}{$\begin{array}{l}\text { Number } \\
\text { of experiments }\end{array}$} & \multirow{2}{*}{$\begin{array}{l}\text { Embryos } \\
\text { transferred }\end{array}$} & \multirow[t]{2}{*}{ Fetuses (\%) } & \multirow[t]{2}{*}{ Resorptions (\%) } & \multirow{2}{*}{$\begin{array}{l}\text { Total } \\
\text { implantations (\%) }\end{array}$} \\
\hline Media & $\overline{\text { Temperature }}$ & & & & & \\
\hline Control & $37^{\circ} \mathrm{C}$ & 5 & 82 & $24(30.6 \pm 2.7)^{a}$ & $19(23.6 \pm 4.09)^{a}$ & $43(57.5 \pm 5.74)^{\text {n.d. }}$ \\
\hline KSOM & $4^{\circ} \mathrm{C}$ & 5 & 92 & $31(32.8 \pm 6.38)^{a}$ & $25(29.8 \pm 8.96)^{\mathrm{ab}}$ & $56(62.59 \pm 5.78)$ \\
\hline KSOM-HEPES & & 5 & 77 & $21(29.5 \pm 6.38)^{a}$ & $26(34.5 \pm 5.27)^{\mathrm{ab}}$ & $47(64.07 \pm 6.90)$ \\
\hline KSOM & $15^{\circ} \mathrm{C}$ & 6 & 86 & $11(13.6 \pm 3.99)^{\mathrm{ab}}$ & $35(40.4 \pm 6.80)^{\mathrm{ab}}$ & $46(53.96 \pm 8.62)$ \\
\hline KSOM-HEPES & & 5 & 80 & $4(4.67 \pm 2.34)^{b}$ & $47(63.9 \pm 13.4)^{b}$ & $51(69.94 \pm 12.89)$ \\
\hline KSOM & $37^{\circ} \mathrm{C}$ & 6 & 90 & $12(16.4 \pm 5.60)^{a b}$ & $40(45.2 \pm 6.35)^{\mathrm{ab}}$ & $52(60.49 \pm 9.15)$ \\
\hline KSOM-HEPES & & 6 & 98 & $17(17.0 \pm 3.76)^{a b}$ & $36(37.8 \pm 8.40)^{\mathrm{ab}}$ & $53(54.81 \pm 9.48)$ \\
\hline
\end{tabular}

Mean \pm SEM. Different letters indicate significant differences between treatments. ANOVA followed by Student-Newman-Kleus post hoc test was performed. 
Table 6 Details of primers used for RT-PCR

\begin{tabular}{|c|c|c|c|c|}
\hline Gen symbol & MGI official name & Primers sequence $\left(5^{\prime}-3^{\prime}\right)$ & Fragment size & Gene bank accesion $n^{\circ}$ \\
\hline \multirow[t]{2}{*}{ Bax } & \multirow[t]{2}{*}{ BCL2-associated $X$ protein } & $5^{\prime}$ CTACTTTGCCAGCAAACTGG & \multirow[t]{2}{*}{159} & \multirow[t]{2}{*}{ NM_007527.3 } \\
\hline & & 3' TCCCAAAGTAGGAGAGGA & & \\
\hline \multirow[t]{2}{*}{$\mathrm{BCl} 2$} & \multirow[t]{2}{*}{ BCL2-like 1} & 5' GGAGCTGGTGGTTGACTTTC & \multirow[t]{2}{*}{517} & \multirow[t]{2}{*}{ NM_009743.4| } \\
\hline & & 3' CTAGGTGGTCATTCAGGTAAG & & \\
\hline \multirow[t]{2}{*}{ ErV4 } & \multirow[t]{2}{*}{ Murine endogenous retovirus- $L$} & 5' TGCTTGGGCTCAGCAACATGG & \multirow[t]{2}{*}{278} & \multirow[t]{2}{*}{ XM_001478088.1| } \\
\hline & & 3' GACAGAATGCCTCATCTATCGT & & \\
\hline \multirow[t]{2}{*}{ lap } & \multirow[t]{2}{*}{ Intracisternal-A particle } & 5' GGGTATTGTTGAGCGTGCGC & \multirow[t]{2}{*}{333} & \multirow[t]{2}{*}{ XM_001477167.1| } \\
\hline & & 3’ TCGGGTGAGTCTTTCTGGTAC & & \\
\hline \multirow[t]{2}{*}{ Terf1 } & \multirow[t]{2}{*}{ Telomeric repeat binding factor 1} & $5^{\prime}$ TTCAACAACCGAACAAGTGTC & \multirow[t]{2}{*}{215} & \multirow[t]{2}{*}{ Mm 4306} \\
\hline & & 3'ТСТСТTТСТСТTСССССТСС & & \\
\hline \multirow[t]{2}{*}{ Cx43 (Gaj1) } & \multirow{2}{*}{$\begin{array}{l}\text { Gap junction membrane channel } \\
\text { protein alpha } 1\end{array}$} & 5'TACCACGCCACCACTGGCCCA & \multirow[t]{2}{*}{290} & \multirow[t]{2}{*}{ Mm 4504} \\
\hline & & 3’ATTCTGGTTGTCGTCGGGGAAATC & & \\
\hline \multirow[t]{2}{*}{ Nanog } & \multirow[t]{2}{*}{ Nanog homebox } & 5'AGGGTCTGCTACTGAGATGCTCTG & \multirow[t]{2}{*}{363} & \multirow[t]{2}{*}{ Mm 6047} \\
\hline & & $3^{\prime}$ CAACCACTGGTIITCTGCCACCG & & \\
\hline \multirow[t]{2}{*}{ Oct3/4 (Pou5f1) } & \multirow[t]{2}{*}{ POU domain, class 5, transcription factor 1} & 5'GGAGAGGTGAAACCGTCCCTAGG & \multirow[t]{2}{*}{312} & \multirow[t]{2}{*}{ Mm 17031} \\
\hline & & 3'AGAGGAGGTTCCCTCTGAGTTGC & & \\
\hline \multirow[t]{2}{*}{ Gapdh } & \multirow[t]{2}{*}{ Glyceraldehyde-3-Phosphate dehydrogenase } & 5'GGGTGTGAACCACGAGAAATATGA & \multirow[t]{2}{*}{250} & \multirow[t]{2}{*}{ Mm 379644} \\
\hline & & 3'CCTTCCACAATGCCAAAGT & & \\
\hline H2afz & Histone H2az & 5'TGTGTACAGCGCAGCCATCCTG & 208 & NM_016750.2 \\
\hline & & 3'CTTCCCGATCAGCGATTTGTGG & & \\
\hline
\end{tabular}

embryos are a reliable method and they can reach any remote location in the world; conversely, fresh embryos remain viable for a limited amount of time and they require careful coordination between sending and receiving facilities. However, they allow the use of simple containers instead of dry shippers and, what is more important: they do not require cryopreservation skills to correctly freeze and thaw embryos.

These advantages have motivated several studies to set up non-frozen transport conditions [24-26]. In most cases, they were circumscribed to the 2-cell stage. The reason to choose this specific developmental stage may

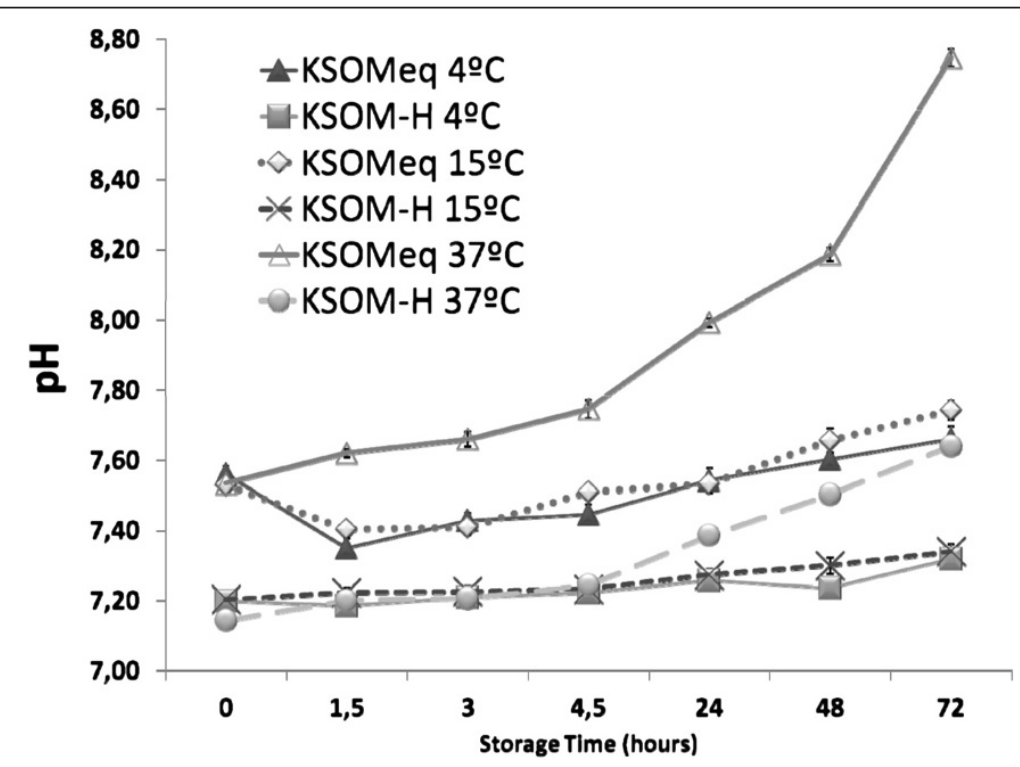

Figure 5 Media pH changes during storage of embryos under different conditions assayed. 

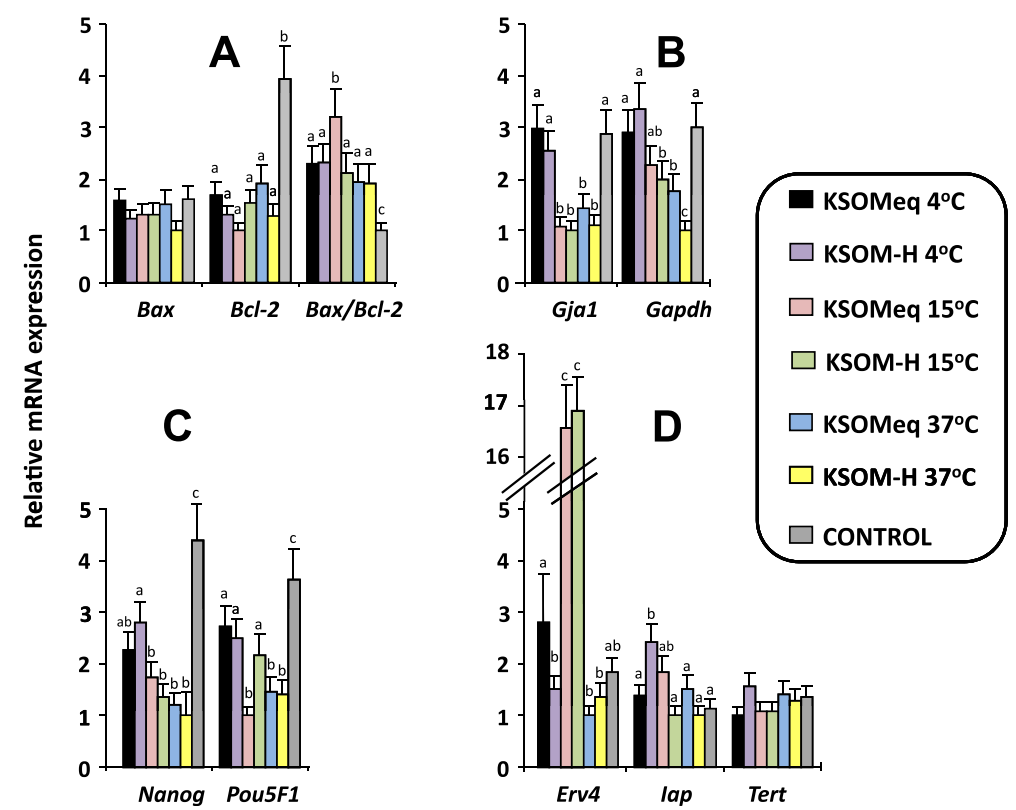

Figure 6 Analysis of mRNA transcription levels for developmentally important genes. Genes assayed were: A) apoptosis (Bax, Bcl2), B) cellto-cell adhesion (Gaj1), and methabolism (Gapdh) C) totipotency (Pou5f1, Nanog) D) retrotransposon expression (Erv4 and lap) and telomere extension (Terf1), after storage for 48 hours in $\mathrm{KSOM}$ and $\mathrm{KSOMh}$ at $4^{\circ} \mathrm{C}, 15^{\circ} \mathrm{C}$ and $37^{\circ} \mathrm{C}$. Mean $\pm \mathrm{SEM}$. Significant differences were denoted by different letters. ANOVA analysis was performed.

rely on providing the more extended length of in vitro culture for positively fertilized embryos. However, this stage poses a risk in certain strains, since 2-cell block mostly appears linked to suboptimal culture conditions [7,27-29].

We wanted to define more universal conditions by exploring different temperatures and the role of $\mathrm{pH}$, comparing an equilibrated versus a HEPES buffered medium. We also chose morula stage, a less restrictive stage since the 2-cell block has already been overcome and there are still 24-48 hours of autonomy. In addition, we explored the feasibility of collecting embryos at 1-cell stage and culturing them to morulae before storage, since collecting embryos from the ampulla is consistently easier than flushing them from the oviduct, and our aim was to define the most accessible way to ship embryos under non-frozen conditions.

Our results in the first experiment demonstrate that in vitro development after 24 hours of storage under the conditions described is not compromised. Our findings showed that, even though there was a significant decrease of cell counts in all treatments with respect to the control group, this did not compromise in vivo viability after transfer. Somehow, the certain delay in development due to storage, which motivates the decrease in total cell numbers in stored embryos, was easily overcome when they were placed in a permissive maternal environment, such as a 0.5 recipient. This demonstrates that successful transfer of morulae after $24 \mathrm{~h}$ of storage can be achieved in any of the media or temperature assayed without compromising in vivo viability. Previous studies have focused on the transport of 2-cell embryos, either thawed after cryopreservation, [30] or obtained from in vitro fertilization [5], achieving $44 \%$ in vivo development for embryos stored at $4^{\circ} \mathrm{C}$ for 48 hours. We obtained higher developmental levels under all the conditions tested, but in our study, embryo transfer was performed after 24 hours of storage. Given the significant decrease of in vitro viability observed when comparing 24 to 48 hours of storage, and the detrimental effect of in vitro embryo culture previous to being subjected to storage conditions, we can assume that for longer storage periods, $4^{\circ} \mathrm{C}$ is more advisable. At $15^{\circ} \mathrm{C}$ or $37^{\circ} \mathrm{C}$, the induced gene deregulation and the decrease in cell count may not be compensated by the maternal environment after transfer, as occurred with $24 \mathrm{~h}$ stored embryos.

The in vivo and in vitro alterations observed after the storage $48 \mathrm{~h}$ may be a consequence of the misregulation of genes with an important role in embryo development. For example, the low percentage of blastocyst development after storage at $15^{\circ} \mathrm{C}$ can be related to the increase in deregulation in $\mathrm{Bax} / \mathrm{Bcl}-2$ ratio and the increase in the retrotrasposon expression observed in this group, since $B c l 2$ Bax ratio has been considered a marker of viability or apoptosis in bovine embryos [31]. 
The cell number decrease observed both in the $15^{\circ} \mathrm{C}$ and $37^{\circ} \mathrm{C}$ groups could be related to the decrease in Nanog and Oct3/4 expression. The expression patterns we found might also suggest a decrease in the pluripotency ability of ICM cells and, to some extent, may be responsible for the failure in postimplantation development found after transfer of stored embryos at $15^{\circ} \mathrm{C}$ $[32,33]$. Expression patterns in the group of embryos stored at $4^{\circ} \mathrm{C}$, were more similar to the patterns observed in the control group, which could also explain the higher percentage of living fetuses obtained after transfer of embryos collected at 1-cell and in vitro cultured prior to storage.

Although several studies have demonstrated embryo ability to develop after long periods under nonphysiological conditions $[6,34]$, we did not intend to analyze culture conditions. Differences between those analyses and the findings presented here are relevant. We focused on defining a way to store embryos from a practical point of view; for this reason, we compared several temperatures instead of focusing only on one. On the other hand, since long- term transport is successfully achieved with frozen embryos, we focused on short-term conditions. Nowadays, most courier transports deliver in 24-48 hours. Therefore the aim of our study was not to examine in depth what the limit for survival of an embryo is under different conditions, but rather if any of the conditions analysed could be addressed as the optimal one for short-term shipment.

Standard embryo holding media, such as M-2 substitute bicarbonate with HEPES, are useful in order to stabilize $\mathrm{pH}$ when embryos are handled; however, bicarbonate is necessary for the optimal development of embryos [34] while being kept at $4^{\circ} \mathrm{C}$. Buffering is not the only role of $\mathrm{NaHCO}_{3}$, since $\mathrm{CO}_{2}$ is required for in vitro embryo development. Carbon from external $\mathrm{CO}_{2}$ is fixed by the embryo and used for various metabolic processes [35,36]. Some authors consider that buffer mixtures as HEPES-MOPS together with $25 \mathrm{mM}$ $\mathrm{NaHCO}_{3}$ are enough to maintain $\mathrm{pH}$ [18].

With this in mind, in our experimental design, bicarbonate was not removed from the medium. KSOM-H consisted of the same standard KSOM medium with $25 \mathrm{mM}$ sodium bicarbonate, supplemented with HEPES, in order to provide $\mathrm{pH}$ buffering ability without reducing the amount of available bicarbonate.

The volume in which embryos were contained is an important parameter. Mouse embryos are sensitive to osmolarity increase [37]; due to this circumstance, and so as to avoid evaporation during storage time, a large volume for the medium was chosen. In addition, $\mathrm{pH}$ buffering is more accurate in large volumes, especially in KSOMeq. For this reason, storage conditions should be considered as a whole, since volume may influence gas interchange and $\mathrm{pH}$ fluctuation.

In this study, most treatments implied a significant reduction in cell numbers in comparison with the control, but these differences did not affect implantation ability [38]. Reduced cell numbers per embryo do not always indicate a decline in the subsequent in vitro or in vivo developmental capacity of embryos, as some authors have reported in other processes, such as cryopreservation [39]. Some theories have been proposed, but essentially, embryos with reduced numbers of cells are still able to give rise to fetuses [40-42]. Nowadays, is not fully understood what the limit is to this situation. It is proposed that ICM cells have an important role in the three germ layer formation of the embryo. If too small, ICM is present, so embryonic endoderm cannot be formed. Although only the embryonic ectoderm gives rise to the embryo proper, the interactions between the three germ layers are necessary for full embryonic and fetal development.

Our aim was to define the easiest way possible to obtain and store embryos for a short time, eliminating the need for cryopreservation. For this reason, in our study, we also tested the feasibility of using morulae obtained after in vitro culture of embryos collected at the 1-cell stage. One cell embryo collection is technically easy, and in vitro culture avoids the necessity of correct identification of fertilized embryos, which requires a certain skill. However, this approach proved to be less efficient. Even though live fetuses were obtained from all storage conditions, there was a sensitive increase in the number of resorptions. This demonstrated that embryos had a compromised viability; they could be implanted, but were incapable of further development. Our results regarding cell counts somehow illustrate that situation: morulae obtained in vitro had a lower total cell number in comparison with the numbers observed on in vivo collected morulae. Even though embryos with reduced cell numbers are able to implant and develop, a low cell count has been associated with lower developmental ability [43].

Our results show that morula is a very permissive developmental stage for $24 \mathrm{~h}$ embryo storage, allowing different temperatures and media conditions without detrimental effects on in vivo viability after transfer. Even though previous in vitro culture seriously compromises embryo viability, this effect is more dramatic when storing under suboptimal conditions, such as $15^{\circ} \mathrm{C}$ where deregulation of important genes became highly significant. But even under such conditions, it was possible to obtain live fetuses after transfer. Since none of the $24 \mathrm{~h}$ storage conditions tested showed a significant improvement or a deleterious effect, there is no scientific basis to choose one or other. Practical preferences are a valid 
criterium to decide on a given temperature. However, if it is suspected a certain delay in the process or previous culture of embryos is necessary, our results based on the higher implantation rates found, suggest that $4^{\circ} \mathrm{C}$ provides a safer margin.

\section{Conclusions}

In conclusion, both KSOMeq and KSOM-H may be equally used for embryo storage, and several temperature conditions allow for good in vitro and in vivo survival. Some of these storage conditions can substitute freezing in order to maintain embryo viability for 24-48 hours, offering a good and technically less demanding alternative for embryo exchanges.

\section{Competing interests}

The authors declare that they have no competing interests.

\section{Authors' contributions}

Experiment conceived and designed by BP, JDH and AGA. Experiment performed by JDH, AS, MPC and BP. Data analyzed by JDH, BP and AGA. Paper discussed and written by JDH, BP, AGA and MPC. All authors read and approved the final manuscript.

\section{Acknowledgements}

This work was performed as part of, and financed by, Project AGL200400332. JDH received a Ph D. grant from the INIA (Ministry of Science and Innovation). We acknowledge support of the publication fee by the CSIC Open Access Publication Support Initiative through its unit of Information Resources for Research (URICI). Language correction has been performed by the Oficina de Asesoría Lingüística of the Autónoma University Foundation.

\section{Author details}

'Dpto. de Reproducción Animal, INIA, Ctra de la Coruña Km 5,9, Madrid 28040, Spain. ${ }^{2}$ Centro Nacional de Biotecnología, CSIC. C/ Darwin 3, Madrid 28049, Spain.

Received: 8 March 2012 Accepted: 7 August 2012

Published: 22 August 2012

\section{References}

1. Gutierrez A, Garde J, Artiga CG, Munoz I, Pintado B: In vitro survival of murine morulae after quick freezing in the presence of chemically defined macromolecules and different cryoprotectants. Theriogenology 1993, 39(5):1111-1120.

2. Rowson LE, Moor RM, Lawson RA: Fertility following egg transfer in the cow; effect of method, medium and synchronization of oestrus. J Reprod Fertil 1969, 18(3):517-523.

3. Polge CAC, Baker RD: Development and survival of pig embryos in the rabbit oviduct. In Proceedings of 7th ICAR Congress. Munich, Germany: 1972:513-517.

4. Lawson RA, Adams CE, Rowson LE: The development of sheep eggs in the rabbit oviduct and their viability after re-transfer to ewes. J Reprod Fertil 1972, 29(1):105-116.

5. Takeo T, Kondo T, Haruguchi $Y$, Fukumoto $K$, Nakagawa $Y$, Takeshita $Y$, Nakamuta Y, Tsuchiyama S, Shimizu N, Hasegawa T: Short-term storage and transport at cold temperatures of 2-cell mouse embryos produced by cryopreserved sperm. J Am Assoc Lab Anim Sci 2010, 49(4):415-419.

6. Herr CM, Wright RW Jr: Cold storage of mouse embryos of different stages of development. Theriogenology 1988, 29(3):765-770.

7. Chatot $\mathrm{CL}$, Ziomek CA, Bavister BD, Lewis JL, Torres I: An improved culture medium supports development of random-bred 1-cell mouse embryos in vitro. J Reprod Fertil 1989, 86(2):679-688.

8. Nagy AGM, Vintersten K, Behringer R: Manipulating the Mouse Embryo. 3rd edition. Cold Spring Harbor Laboratory Press: A Laboratory Manual; 2003.
9. Erbach GT, Lawitts JA, Papaioannou VE, Biggers JD: Differential growth of the mouse preimplantation embryo in chemically defined media. Biol Reprod 1994, 50(5):1027-1033

10. Fernandez-Gonzalez R, de Dios Hourcade J, Lopez-Vidriero I, Benguria A, De Fonseca FR, Gutierrez-Adan A: Analysis of gene transcription alterations at the blastocyst stage related to the long-term consequences of in vitro culture in mice. Reproduction 2009, 137(2):271-283.

11. Fernandez-Gonzalez R, Ramirez MA, Pericuesta E, Calle A, Gutierrez-Adan A: Histone modifications at the blastocyst Axin1(Fu) locus mark the heritability of in vitro culture-induced epigenetic alterations in mice. Biol Reprod 2010, 83(5):720-727.

12. Carnevale EM, Squires EL, McKinnon AO: Comparison of Ham's F10 with $\mathrm{CO} 2$ or Hepes buffer for storage of equine embryos at $5 \mathrm{C}$ for $24 \mathrm{H}$. J Anim Sci 1987, 65(6):1775-1781.

13. Carney NJ, Squires EL, Cook VM, Seidel GE Jr, Jasko DJ: Comparison of pregnancy rates from transfer of fresh versus cooled, transported equine embryos. Theriogenology 1991, 36(1):23-32.

14. Davis DL: Culture and storage of pig embryos. J Reprod Fertil Supp/ 1985, 33:115-124.

15. Lane $M$, Gardner DK: Differential regulation of mouse embryo development and viability by amino acids. J Reprod Fertil 1997, 109(1):153-164.

16. Sakkas D, Gardner DK: Noninvasive methods to assess embryo quality. Curr Opin Obstet Gynecol 2005, 17(3):283-288.

17. Will MA, Clark NA, Swain JE: Biological pH buffers in IVF: help or hindrance to success. J Assist Reprod Genet 2011, 28(8):711-724

18. Swain JE: A self-contained culture platform using carbon dioxide produced from a chemical reaction supports mouse blastocyst development in vitro. J Reprod Dev 2011, 57(4):551-555.

19. Reetz IC, Wullenweber-Schmidt M, Kraft V, Hedrich HJ: Rederivation of inbred strains of mice by means of embryo transfer. Lab Anim Sci 1988, 38(6):696-701.

20. Suzuki H, Togashi M, Kumagai E, Miwa M, Tatsumi T, Nakura M, Nakagawa T, Tanaka N, Adachi J: An attempt at embryo transfer as a means of controlling Bordetella bronchiseptica infection in the rabbit. Jikken Dobutsu 1990, 39(3):397-400.

21. Whittingham DG, Whitten WK: Long-term storage and aerial transport of frozen mouse embryos. J Reprod Fertil 1974, 36(2):433-435.

22. Bilton RJ, Moore NW: Successful transport of frozen cattle embryos from New Zealand to Australia. J Reprod Fertil 1977, 50(2):363-364.

23. Shelton JN: Prospects for the use of embryos in the control of disease and the transport of genotypes. Aust Vet J 1987, 64(1):6-10.

24. Kasai M: Nonfreezing technique for short-term storage of mouse embryos. J In Vitro Fert Embryo Transf 1986, 3(1):10-14.

25. Kasai M, Niwa K, Iritani A: Protective effect of sucrose on the survival of mouse and rat embryos stored at 0 degree C. J Reprod Fertil 1983, 68(2):377-380

26. Kasai M, Niwa K, Iritani A: Effects of various cryoprotective agents on the survival of unfrozen and frozen mouse embryos. J Reprod Fertil 1981 63(1):175-180

27. Lawitts JA, Biggers JD: Overcoming the 2-cell block by modifying standard components in a mouse embryo culture medium. Biol Reprod 1991, 45(2):245-251.

28. Qiu JJ, Zhang WW, Wu ZL, Wang YH, Qian M, Li YP: Delay of ZGA initiation occurred in 2-cell blocked mouse embryos. Cell Res 2003, 13(3):179-185

29. Zanoni M, Garagna S, Redi CA, Zuccotti M: The 2-cell block occurring during development of outbred mouse embryos is rescued by cytoplasmic factors present in inbred metaphase II oocytes. Int J Dev Biol 2009, 53(1):129-134

30. Takeo T, Kaneko T, Haruguchi Y, Fukumoto K, Machida H, Koga M, Nakagawa Y, Takeshita Y, Matsuguma T, Tsuchiyama S, et al: Birth of mice from vitrified/warmed 2-cell embryos transported at a cold temperature. Cryobiology 2009, 58(2):196-202.

31. Yang MY, Rajamahendran R: Expression of $\mathrm{Bcl}-2$ and Bax proteins in relation to quality of bovine oocytes and embryos produced in vitro. Anim Reprod Sci 2002, 70(3-4):159-169.

32. Hiiragi T, Dietrich J-E: Stochastic patterning in the mouse pre-implantation embryo. Development 2007, 134:4219-4231.

33. Yamanaka S: Pluripotency and nuclear reprogramming. Phil. Trans. $R$ Soc $B$ 2008, 363:2079-2087. 
34. Herr CM, Wright R Jr: Cold culture of different stage mouse embryos in bicarbonated and bicarbonate-free media. Theriogenology 1988, 30(1):159-168.

35. Pike IL, Murdoch RN, Wales RG: The incorporation of carbon dioxide into the major classes of RNA during culture of the preimplantation mouse embryo. J Reprod Fertil 1975, 45(2):211-226.

36. Graves CN, Biggers JD: Carbon dioxide fixation by mouse embryos prior to implantation. Science 1970, 167(3924):1506-1508.

37. Baltz JM, Tartia AP: Cell volume regulation in oocytes and early embryos: connecting physiology to successful culture media. Hum Reprod Update 2010, 16(2):166-176.

38. Kasai M, Ito K, Edashige K: Morphological appearance of the cryopreserved mouse blastocyst as a tool to identify the type of cryoinjury. Hum Reprod 2002, 17(7):1863-1874.

39. Ling XF, Zhang JQ, Cao SR, Chen J, Peng Y, Guo X, Heng BC, Tong GQ, Wang $X$ : Effect of cryotop vitrification on preimplantation developmental competence of murine morula and blastocyst stage embryos. Reprod Biomed Online 2009, 19(5):708-713.

40. Willadsen SM, Polge C: Attempts to produce monozygotic quadruplets in cattle by blastomere separation. Vet Rec 1981, 108(10):211-213.

41. Iwasaki S, Yoshiba N, Ushijima H, Watanabe S, Nakahara T: Morphology and proportion of inner cell mass of bovine blastocysts fertilized in vitro and in vivo. J Reprod Fertil 1990, 90(1):279-284.

42. Tao T, Reichelt B, Niemann H: Ratio of inner cell mass and trophoblastic cells in demi- and intact pig embryos. J Reprod Fertil 1995, 104(2):251-258.

43. Scott L, Whittingham DG: Influence of genetic background and media components on the development of mouse embryos in vitro. Mol Reprod Dev 1996, 43(3):336-346.

doi:10.1186/1477-7827-10-62

Cite this article as: Hourcade: In vitro and in vivo development of mice morulae after storage in non-frozen conditions. Reproductive Biology and Endocrinology 2012 10:62.

\section{Submit your next manuscript to BioMed Central and take full advantage of:}

- Convenient online submission

- Thorough peer review

- No space constraints or color figure charges

- Immediate publication on acceptance

- Inclusion in PubMed, CAS, Scopus and Google Scholar

- Research which is freely available for redistribution 